\title{
SOIL CHEMICAL ATTRIBUTES AND INITIAL GROWTH OF CORN CROP BY ADDING DOMESTIC AND INDUSTRIAL SEWAGE SLUDGE
}

\author{
ATRIBUTOS QUÍMICOS DO SOLO E CRESCIMENTO INICIAL DE MILHO PELA \\ ADIÇÃO DE LODOS DE ESGOTO DOMÉSTICO E INDUSTRIAL
}

\section{Cácio Luiz BOECHAT ${ }^{\mathbf{1}}$; Adriana Miranda de Santana ARAUCO ${ }^{\mathbf{1}}$; Marcos de Oliveira RIBEIRO ${ }^{2}$; Ana Clécia Campos BRITO ${ }^{3}$; Aurino Azevedo de SOUZA ${ }^{4}$; Jorge Antonio Gonzaga SANTOS ${ }^{5}$}

1. Professor (a) efetivo (a), Campus Prof ${ }^{a}$ Cinobelina Elvas, Universidade Federal do Piauí, Bom Jesus, PI, Brasil. cacioboechat@gmail.com; 2. Mestre em Solos e Qualidade de Ecossistemas, Universidade Federal do Recôncavo da Bahia; 3. Mestranda em Solos e Nutrição de Plantas, Campus Prof ${ }^{a}$ Cinobelina Elvas, Universidade Federal do Piauí, Bom Jesus, PI, Brasil; 4. Professor efetivo, Instituto Federal de Educação do Piauí, Campus Corrente, PI, Brasil; 5. Professor titular, Universidade Federal do Recôncavo da Bahia.

\begin{abstract}
In recent decades, organic and/or inorganic nonconventional waste such as sewage sludge, agroindustrial or industrial waste, inorganic waste, steel slag, etc., have become some of the most promising alternatives to commercial fertilizer shortages or rising prices. Hence, the aim was to evaluate morphological changes in corn plants and variations in chemical properties of cohesive Yellow Latosol (Oxisol), after the incorporation of sewage sludge doses from domestic waste and the dairy industry. The experimental units were randomised blocks designed with four repetitions. The treatments consisted of five doses of each sewage sludge incorporated into the soil, that is: Domestic Sewage Sludge (DSS) in doses of $0.0 ; 3.1 ; 4.6 ; 6.1$ and $9.2 \mathrm{Mg} \mathrm{ha}^{-1}$ (on a dry basis ), and Industrial Sewage Sludge (ISS) in doses of 0.0; $5.2 ; 7.8 ; 10.4$ e $15.6 \mathrm{Mg} \mathrm{ha}^{-1}$ (on a dry basis), all equivalent to $0 ; 100 ; 150 ; 200$ and $300 \mathrm{~kg}$ of total $\mathrm{N}^{-1}$. Doses equivalent to $150-300 \mathrm{~kg}$ total $\mathrm{N} \mathrm{ha}^{-1}$ led to greater gains in stem diameter, number of leaves, fresh and dry mass of leaves. Increasing doses of both sewage sludges enable gains in the morphological variables studied, except for root length. Positive linear increments occur in the $\mathrm{pH}$ and phosphorus content of soils when the doses of sewage sludge are increased. The exchangeable aluminium and potential acidity are reduced, from the first dose of industrial sewage sludge, with no significant difference for domestic sewage sludge.
\end{abstract}

KEYWORDS: Organic waste. Organic fertilizer. Industrial disposal. Domestic disposal. Zea mays.

\section{INTRODUCTION}

In the various types of wastewater treatment systems a semi-solid residue, in the form of a slurry, and with a predominantly organic nature occurs called sewage sludge. The use of sewage sludge in agriculture is still very questionable, due to the damage it can cause to human health and the natural environment, besides financial losses if it is incorrectly used (BONINI et al., 2015). A feasible technical alternative to the reuse of organic wastes is their use as organic fertilizer, provided that no heavy metals, pathogens and toxic components are present. Additionally, the potential for soil salinization and acidification has to be considered. Its value as fertilizer is very high because of the high level of nitrogen and organic matter (PIRES; MATTIAZZO, 2008). For the use of sewage sludge, the reuse technique of this compound and its derivatives is the only one that follows Brazilian legislation defined by CONAMA $n^{\circ} 375 / 2006$. Although specific to sewage sludge, the effluent may be classified under some rule of this legislation.
The composition of sewage sludge is variable because of its origin which can be residential or industrial, and it also depends on the treatment process that is applied. Basically, the sewage sludge contains potassium, phosphorus, organic matter, nitrogen, macro and micronutrients (BONINI et al., 2015; BOECHAT et al., 2014a). Over the years, the chemical, biological and physical properties of soil in traditional cropping systems have been declining. This trend is noticeable because it has caused physical deterioration of the soil and its microecosystems as well as of soil workability. The continuous transformation of soil organic matter (SOM) into arid and semiarid regions can lead to soil degradation as a consequence of the lack of capacity to ensure sustainable (CAMPOS; ALVES, 2008).

Several studies show the importance of nonconventional wastes in improving chemical, physical and biological attributes of the soil as a result of organic matter increments and intrinsic characteristics of its materials. These include compaction (CAMPOS; ALVES, 2008), water infiltration capacity into soil (ALVES et al., 2007), 
microorganism activity (BOECHAT et al., 2012), edaphic fauna enrichment (KITAMURA et al., 2008), chemical soil improvements (BONINI et al., 2015; KITAMURA et al., 2008), and still increasing crop productivity (CALDEIRA et al., 2014; SHABANI, 2011). Moreover, there is a huge need for continuous research about the disposal and reuse of sewage sludge produced by wastewater treatment plants (WWTP) and investiments and commitment of the government and society are needed to seek alternatives for the disposal of this waste.

In this context, this study aimed to evaluate morphological alterations in corn plants and chemical properties of a cohesive Oxisol after incorporation into the soil of sludge doses from domestic and dairy industry sewage treatment sludges.

\section{MATERIAL E METHODS}

Two experiments were carried out under greenhouse conditions at geographic coordinates $12^{\circ}$ 40 ' 00' S latitude, $39^{\circ} 06^{\prime} 00^{\prime \prime}$ W longitude; $220 \mathrm{~m}$ asl and average annual temperature of $24.5^{\circ} \mathrm{C}$. Noncomposted sewage sludges (industrial and domestic sewage sludge) were used in each experiment. Table 1 shows the average monthly values of air temperature and relative humidity during the experimental period.

Table 1. Average monthly air temperature $\left({ }^{\circ} \mathrm{C}\right)$ and relative humidity $(\%)$ based on the climatic conditions during the experimental period.

\begin{tabular}{lll}
\hline Month & $\begin{array}{l}\text { Average } \\
\text { Temperature }\left({ }^{\circ} \mathrm{C}\right)\end{array}$ & Relative \\
& 20.84 & Humidity $(\%)$ \\
\hline August & 21.87 & 87.88 \\
September & 24.38 & 86.83 \\
October & 25.54 & 84.36 \\
November & 25.75 & 77.07 \\
December & 79.07 \\
\hline
\end{tabular}

The industrial sewage sludge (ISS) was acquired from the dairy industry, and is formed by the processing of milk to manufacture cheeses and butter. The industrial organic wastes are placed in an aerated lagoon to reduce organic load with lime application $(\mathrm{CaO})$. This process eliminates odours, pathogens, and promotes stabilisation of organic material. Then, these wastes are pumped to a settling pond where the solid part passes through a filter press. Finally, it generates a sludge ("organic pie").

Domestic sewage sludge (DSS) is produced by a municipal sewage treatment plant that uses a physical process to remove suspended and floating solids. Then, the biological treatment using aerobic activated sludge reduces the biochemical oxygen demand (BOD) and biodegradation occurs in an anaerobic reactor to reduce the organic load by dehydration of the sewage sludge on a drying bed.

The soil was classified as a Latossolo Amarelo coeso according to the Brazilian System of Soil Classification (SANTOS et al., 2013) and as an Oxisol according to Soil Survey Staff (2014), with a sandy loam texture. The soil sample was collected at a depth of 0-20 cm within the profile and air-dried. The soil was sieved through a $2.0 \mathrm{~mm}$ mesh, homogenised. The chemical analysis of soil sample and sewage sludge was performed based on Tedesco et al. (1995). Table 2 displays the chemical characteristics of the soil and the sewage sludge.

Table 2. Soil Chemical attributes of the domestic and industrial sewage sludge used in this study.

\begin{tabular}{|c|c|c|c|c|c|c|c|c|c|c|c|c|c|}
\hline Attribu & $\begin{array}{l}\mathrm{pH} \\
\mathrm{H}_{2} \mathrm{O} \\
\end{array}$ & $\begin{array}{l}\mathrm{P} \\
\mathrm{g} \mathrm{dm}^{-3}\end{array}$ & $\mathrm{Ca}$ & $\begin{array}{r}\mathrm{Mg} \\
\mathrm{cmol}_{\mathrm{c}} \\
\end{array}$ & $\begin{array}{l}\mathrm{K} \\
\mathrm{dm}^{-3}\end{array}$ & $\begin{array}{c}\text { CEC } \\
- \\
\end{array}$ & $\begin{array}{l}\text { TOC } \\
-\mathrm{g} \\
\end{array}$ & $\begin{array}{l}\mathrm{SOM} \\
\mathrm{kg}^{-1}\end{array}$ & $\mathrm{~N}$-total & $\mathrm{Cu}_{1}$ & $\begin{array}{c}\mathrm{Mn} \\
\mathrm{mg} \mathrm{kg}^{-1} \\
\end{array}$ & $\begin{array}{r}\mathrm{Pb} \\
- \\
\end{array}$ & $\begin{array}{l}\mathrm{C}: \mathrm{N} \\
- \\
\end{array}$ \\
\hline DSS & 5.7 & 9.5 & 12.0 & 3.3 & - & - & 235.0 & 405.1 & 32.6 & 334.0 & 113.4 & 8.5 & 7.2 \\
\hline ISS & 6.9 & 15.0 & 39.6 & 1.6 & - & - & 161.6 & 278.6 & 19.2 & 141.8 & 292.3 & 44.4 & 8.4 \\
\hline Soil & 5.2 & 0.002 & 0.46 & 0.4 & 0.04 & 3.0 & 3.5 & 6.1 & 1.1 & 20.6 & 138.3 & 3.5 & - \\
\hline
\end{tabular}

DSS - Domestic Sewage Sludge; ISS - Industrial Sewage Sludge; $\mathrm{pH}$ in water (1:2.5 ratio); CEC - Cation Exchange Capacity at pH of 7.0; TOC - Total Organic Carbon; SOM - Soil Organic Matter; C:N -carbon/nitrogen ratio.

The experiments were carried out using a randomised block design and replicated four times.
The treatments consisted of five doses of each sludge incorporated into the soil with: DSS in doses 
of $0.0 ; 3.1 ; 4.6 ; 6.1$ and $9.2 \mathrm{Mg} \mathrm{ha}^{-1}$ (on a dry basis), and ISS in doses of $0.0 ; 5.2 ; 7.8 ; 10.4$ and $15.6 \mathrm{Mg}$ $\mathrm{ha}^{-1}$ (on a dry basis), all equivalent to $0 ; 100 ; 150$; 200 and $300 \mathrm{~kg}$ of total $\mathrm{N} \mathrm{ha}^{-1}$.

The plots consisted of PVC columns $75 \mathrm{~mm}$ in diameter and $20 \mathrm{~cm}$ high. Corn seeds were soaked in water for 24 hours and then manually sown fourby-four at a $5 \mathrm{~cm}$ depth. After emergence, plants were thinned to one (the most vigorous) per column. Humidity was kept within a range of $70 \%$ of water retention capacity through periodic weighing of the experimental units and water losses by evapotranspiration.

Additionally, 45 days after emergence (DAE) the following parameters were measured: length of aerial part (LAP), root length (RL), number of leaves (NL), stem diameter (SD), fresh mass of the aerial part (FMAP), fresh mass of root (FMR), dry mass of the aerial part (DMAP), dry mass of root (DMR). The weight of phytomass was evaluated by taking plant weight, plant measurements and then leaf samples of these plants were dried) at $65^{\circ} \mathrm{C}$ for 72 hours in a forced air oven. After that, they were weighed again. At the end of the experiments, soil samples were collected at depth within the $0-20 \mathrm{~cm}$ profile, air-dried, the soil was sieved through a $2.0 \mathrm{~mm}$ mesh, homogenised and then chemically analysed according to Tedesco et al. (1995).

Data were subjected to analysis of variance (ANOVA) by F-test. However, when the effect of sewage sludge doses was significant, regression analysis was applied at a significance level of 0.05 using Sisvar statistical software (FERREIRA, 2011).

\section{RESULTS AND DISCUSSION}

The analysis of variance of the variables studied as a function of domestic sewage sludge (DSS) doses is presented in Table 3. The use of DSS allows different increments at $1 \%$ significance level for aerial part (LAP), stem diameter (SD), fresh mass of the aerial part (FMAP), fresh mass of root (FMR), dry mass of the aerial part (DMAP), dry mass of root (DMR) and at 5\% significance level for number of leaves (NL) (Table 3 ). These results were expected because DSS is rich in nutrients and the corn crop responds better to organic fertilising, for example poultry litter (WALTER et al., 2009). However, root length (RL) did not respond to DSS doses (Table 3).

Table 3. ANOVA summary of length of aerial part (LAP), root length (RL), number of leaves (NL), stem diameter (SD), fresh mass of the aerial part (FMAP), dry mass of the aerial part (DMAP), fresh mass of roots (FMR), and dry mass of roots (DMR) of corn plants depending on doses of domestic sewage sludge (DSS).

\begin{tabular}{llllllllll}
\hline & & \multicolumn{7}{l}{ Mean Square } \\
\cline { 2 - 9 } SV & DF & LAP & RL & NL & SD & FMAP & FMR & DMAP & DMR \\
\hline Dose & 4 & $19.65^{*}$ & $1.87^{\text {ns }}$ & $2.05^{* *}$ & $0.05^{*}$ & $8.00^{*}$ & $48.92^{*}$ & $4.00^{*}$ & $1.26^{*}$ \\
Block & 3 & 1.20 & 0.57 & 0.33 & 0.003 & 0.06 & 2.42 & 0.01 & 0.05 \\
Error & 12 & 0.41 & 0.85 & 0.25 & 0.004 & 0.39 & 2.95 & 0.02 & 0.03 \\
\hline C.V. (\%) & 6.20 & 3.20 & 6.02 & 10.73 & 15.99 & 16.47 & 13.71 & 11.28 \\
\hline
\end{tabular}

Nevertheless, Table 4 shows the analysis of variance of the variables studied as a function of industrial sewage sludge (ISS) doses. The ISS stimulated increments for LAP, FMAP, FMR, DMAP, DMR at $1 \%$ significance level and at 5\% significance level for NF and SD. Additionally, RL did not respond to ISS doses. Camargo et al. (2010) evaluated the root system of papaya using different doses of sewage sludge and they did not observe significant differences in root length. However, Boechat et al. (2014b) observed that incorporation of industrial sewage sludge caused a slight increase in RL in Jatropha curcas plants ranging from the observed value of $11.08 \mathrm{~cm}$ for the lowest value (dose 0 ) to $13.28 \mathrm{~cm}$ for the highest value ( $200 \mathrm{~kg}$ of total $\mathrm{Nha}^{-1}$ ). 
Table 4. ANOVA summary of length of aerial part (LAP), root length (RL), number of leaves (NL), stem diameter (SD), fresh mass of the aerial part (FMAP), dry mass of the aerial part (DMAP), fresh mass of roots (FMR), and dry mass of roots (DMR) of corn plants depending on doses of industrial sewage sludge (ISS).

\begin{tabular}{|c|c|c|c|c|c|c|c|c|c|}
\hline \multirow[b]{2}{*}{ SV } & \multirow[b]{2}{*}{$\mathrm{DF}$} & \multicolumn{8}{|c|}{ Mean Square } \\
\hline & & LAP & $\mathrm{RL}$ & NL & SD & FMAP & FMR & DMAP & DMR \\
\hline Dose & 4 & $10.30^{*}$ & $0.61^{\mathrm{ns}}$ & $2.50 * *$ & $0.04 * *$ & $5.60 *$ & $48.92 *$ & $113.71 *$ & $0.28 *$ \\
\hline Block & 3 & 0.34 & 1.41 & 0.05 & 0.002 & 0.25 & 2.42 & 0.70 & 0.005 \\
\hline Error & 12 & 0.82 & 2.17 & 0.30 & 0.005 & 0.06 & 2.95 & 0.97 & 0.003 \\
\hline \multicolumn{2}{|c|}{ C.V. $(\%)$} & 9.53 & 5.78 & 6.64 & 12.56 & 6.69 & 16.47 & 6.07 & 6.11 \\
\hline
\end{tabular}

*- Significant effect at the $1 \%$ level of probability by F-test; **- Significant effect at the $5 \%$ level of probability by F-test; ns - not significant effect by F-test.

The root system acts as a foundation, so that the plant can remain on the soil. Thus, the root system is responsible for providing support to a plant and plays an important role in the synthesis of phytohormones, and the absorption of water and nutrients by plants (MAGALHÃES, 1988). The volume and distribution of the plant roots increase when the soil is less fertile and there is a greater water deficit. Therefore, the larger the root system of a crop, the greater is its ability to exploit available nutrients and water in the soil (KORNDÖRFER et al., 1989). However, there was no significant difference in RL between both treatments (ISS and DSS) compared to the control treatment.

Berilli et al. (2014) observed similar results for the root system of "Conilon" coffee using tannery sludge in seedling production. Thus, they suggested the hypothesis that tannery sludge could only interfere in the development of the aerial part of this crop. However, Silva et al. (2011) observed that the use of substrates based on composted tannery sludge led to the quick emergence of pepper seedlings and the roots showed better conformation and volume using composted tannery sludge associated with $10 \%$ vermiculite.

It was observed that the LPA increased with increasing doses of DSS (up to $6.1 \mathrm{Mg} \mathrm{ha}^{-1}$ ) and ISS (up to $10.4 \mathrm{Mg} \mathrm{ha}^{-1}$ ) equivalent to $200 \mathrm{~kg}$ of total $\mathrm{N}$ incorporated into the soil. Therefore, it had a significant quadratic model to the two response variables (Figure 1A). Nevertheless, the LAP of corn presented a better response to DSS. Based on the DSS dose of $6.1 \mathrm{Mg} \mathrm{ha}^{-1}$ and ISS dose of 10.1 $\mathrm{Mg} \mathrm{ha}^{-1}$, there was a slight decrease in the LPA of corn plants. This demonstrates that corn did not respond satisfactorily when larger doses of DSS and ISS were applied.

The absolute growth in plant height can be seen by the application of organic residuals to the soil because organic residuals have the ability to improve physical, biological and chemical soil conditions which are essential for rapid plant growth. However, points out that the nutrients required in the greatest amount by corn are the macronutrients nitrogen and potassium (MOREIRA; SIQUEIRA, 2006). Additionally, he says that about $185 \mathrm{~kg} \mathrm{ha}^{-1}$ of $\mathrm{N}$ are required to achieve a grain production of $9.20 \mathrm{t} \mathrm{ha}^{-1}$. Thus, the response of corn plants to increasing doses of nitrogen in this paper may be related to the genetic material and the available nitrogen in the soil.

Evaluating the number of leaves per plant, a positive response with linear adjustment was found for both wastes, and the number of leaves increased together with the doses of waste reaching the maximum number of leaves at the dose of $300 \mathrm{~kg}$ ha $^{-1}$ (Fig. 1B). This involves the amount of nitrogen in the early stages of corn development (Rambo et al., 2011). The number of fully expanded leaves is crucial to the success of the corn crop because it increases the photosynthetic rate.

The evaluation of the stem diameter parameter showed a strong influence of sewage sludge wastes on its development. Besides the number of leaves, its best performance was at the highest dose of $300 \mathrm{~kg} \mathrm{ha}^{-1}$ (Fig. 1C). However, the difference between the DSS and ISS was practically nil emphasizing that both have a similar potential to stimulate NL and SD. Therefore, $\mathrm{N}$ values were determinant for foliage yield and stem diameter development in the corn crop. This was a similar response to that obtained by Magalhães et al. (2014) when they studied maize growth under cassava wastewater fertilisation submitted to increasing doses of starch effluent in substitution for mineral fertilisation. However, Camargo et al. (2010) working with the Jatropha culture observed that as they increased the biosolid doses, stem diameter values decreased. 

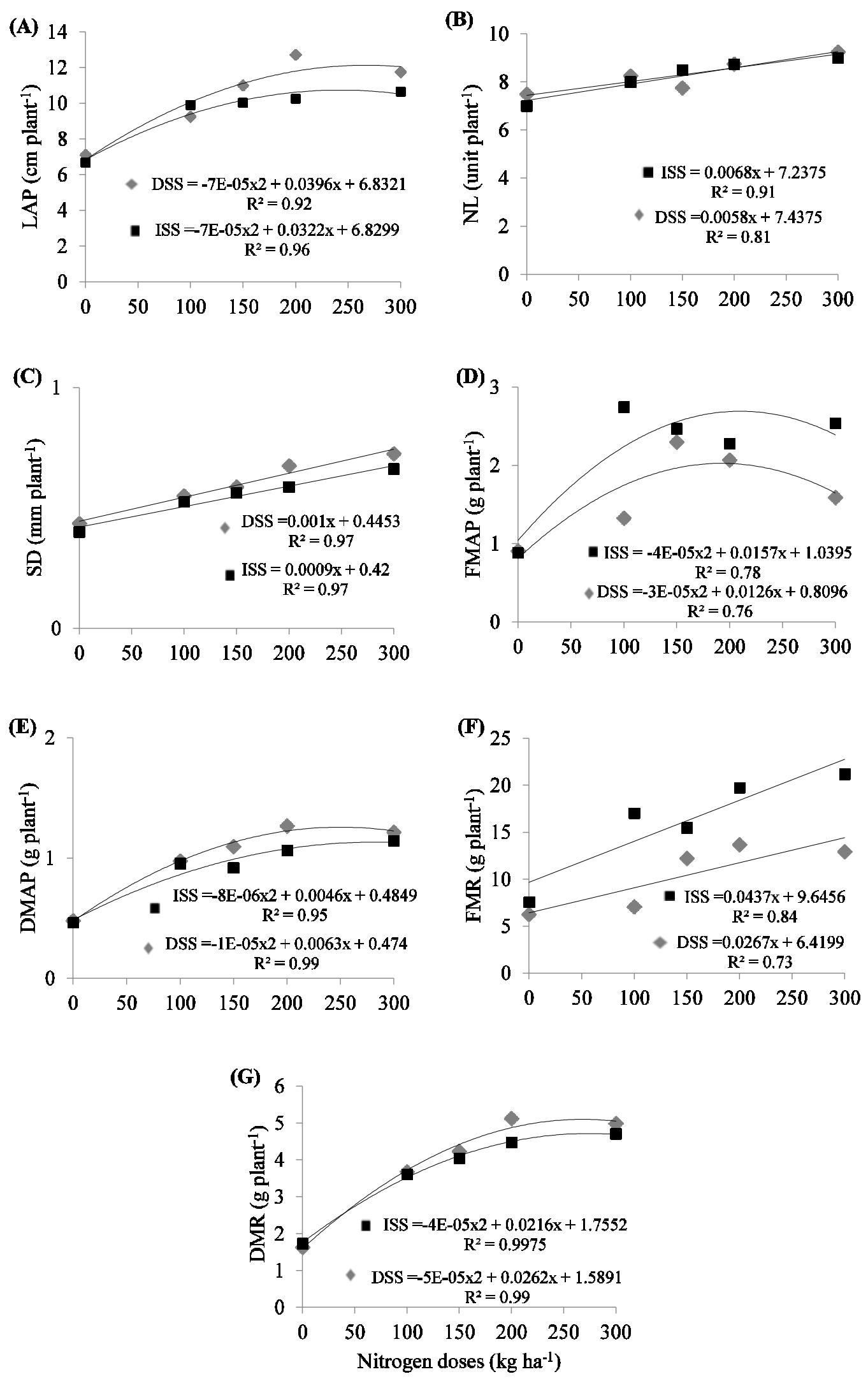

Figure 1. Length of the aerial part, number of leaves, stem diameter, fresh and dry mass of the aerial part, fresh and dry mass of roots of corn plants were grown in soil fertilised with doses of DSS ( ) and ISS (घ). 
Data on the aboveground biomass express the robustness and permanence of the plant in the environment. The experiments showed a great potential for both DSS and ISS wastes in the increase of fresh and dry mass of the aerial part, besides a strong correlation between the DSS and ISS doses (Figures 1D and 1E). These results corroborate and show that the use of these organic residues as alternative sources can replace commercial mineral fertilizers because they provide all essential nutrients for crop growth and productivity (BOECHAT et al., 2015).

When doses of wastes are added to the soil, especially between the zero dose (control) and the dose of $100 \mathrm{~kg}$ total $\mathrm{N} \mathrm{ha}^{-1}$, the values of the two variables analysed show a positive increase rate. The increase in the dose, from 100 to $200 \mathrm{~kg} \mathrm{ha}^{-1}$, also promotes excellent results, especially with regard to domestic sewage sludge which reached its maximum yield at $200 \mathrm{~kg} \mathrm{ha}^{-1}$.

Nitrogen influences several characteristics of the corn crop such as plant height, number of grains per row, stem diameter, ear insertion height, ear diameter, ear length, number of grains per ear, chlorophyll content, among others (Carmo et al., 2012). The maximum production of fresh and dry mass of the aerial part begins with the dose of 200 $\mathrm{kg} \mathrm{ha}^{-1}$ by applying DSS wastes. This is related to the amount of $\mathrm{N}$ present in the waste. Thomaz et al. (2012) observed a significant response in the dry mass yield in the sunflower crop with increasing sewage sludge doses. This consolidates the results found, since the dry mass of the aerial part, expresses success in crop development and its tendency to achieve a good grain yield.

The analysis of fresh root mass resulted in a positive and linear correlation for both types of residuals studied and the dry mass in a polynomial model with maximum values between the dose of 200 and $300 \mathrm{~kg}$ total $\mathrm{N} \mathrm{ha}^{-1}$ (Figures $1 \mathrm{~F}$ and $1 \mathrm{G}$ ). However, there are no significant differences between treatments for the root length parameter in the ANOVA table indicating that a root elongation occurred in the control treatment. This possibly arose as a plant strategy due to lower nutrient availability resulting in greater length, but smaller biomass. The availability of nutrients that occurs by adding sewage sludges allows the root system to develop homogeneously. This increases the volume of exploited soil that allows improving nutrient absorption.

The largest dry mass of roots was observed in the sewage sludge dose equivalent to $300 \mathrm{~kg}$ total $\mathrm{N} \mathrm{ha}^{-1}$ (Figure $1 \mathrm{G}$ ) with the dry mass ranging from 6.24 to $7.54 \mathrm{~g} \mathrm{plant}^{-1}$ and the control treatment ranging from 12.93 to $21.19 \mathrm{~g}$ plant $^{-1}$ (DSS and ISS, respectively). Those can be explained by the chemical characteristics of both wastes (Table 2).

The ANOVA of the variables studied in the soil according to the doses of DSS and ISS are in Tables 5 and 6 . The use of DSS promoted increments at $1 \%$ significance level for parameters soil $\mathrm{pH}, \mathrm{Ca}^{2+}+\mathrm{Mg}^{2+}, \mathrm{S}$ and at $5 \%$ significance level for $\mathrm{P}$ (Table 5). Nevertheless, there is no significant response to doses of DSS for parameters $\mathrm{K}^{+}, \mathrm{Al}^{+3}$, $\mathrm{H}+\mathrm{Al}$ and $\mathrm{Na}^{+}$(Table 5).

Table 5. ANOVA summary of soil $\mathrm{pH}$ in water $(\mathrm{pH})$, phosphorus $(\mathrm{P})$, potassium $\left(\mathrm{K}^{+}\right)$, calcium and magnesium $\left(\mathrm{Ca}^{2+}+\mathrm{Mg}^{2+}\right)$, exchangeable aluminum $\left(\mathrm{Al}^{+3}\right)$, potential acidity $(\mathrm{H}+\mathrm{Al})$, sodium $\left(\mathrm{Na}^{+}\right)$, and sum of bases (S) in soil cultivated with corn and fertilised with doses of domestic sewage sludge (DSS).

\begin{tabular}{llllllllll}
\hline & \multicolumn{9}{l}{ Mean Square } \\
\cline { 3 - 10 } SV & DF & $\mathrm{pH}$ & $\mathrm{P}$ & $\mathrm{K}^{+}$ & $\mathrm{Ca}^{2+}+\mathrm{Mg}^{2+}$ & $\mathrm{Al}^{+3}$ & $\mathrm{H}+\mathrm{Al}$ & $\mathrm{Na}^{+}$ & $\mathrm{S}$ \\
\hline Dose & 4 & $1.28^{*}$ & $918.18^{* *}$ & $0.002^{\mathrm{ns}}$ & $1.14^{*}$ & $0.01^{\mathrm{ns}}$ & $0.03^{\text {ns }}$ & $0.0003^{\text {ns }}$ & $1.28^{*}$ \\
Block & 3 & 0.04 & 88.18 & 0.0007 & 0.02 & 0.01 & 0.02 & 0.0001 & 0.03 \\
Error & 12 & 0.06 & 88.81 & 0.0005 & 0.03 & 0.008 & 0.07 & 0.0003 & 0.03 \\
\hline C.V. (\%) & & 4.96 & 39.35 & 30.21 & 14.52 & 28.25 & 16.72 & 49.53 & 15.23
\end{tabular}

*- Significant effect at the $1 \%$ level of probability by F-test; **- Significant effect at the $5 \%$ level of probability by F-test; ns - not significant effect by F-test.

Table 6 shows the ANOVA summary based on ISS doses. The ISS promoted increments at $1 \%$ significance level for parameters $\mathrm{pH}, \mathrm{P}, \mathrm{Ca}^{2+}+\mathrm{Mg}^{2+}$, $\mathrm{Al}^{+3}, \mathrm{H}+\mathrm{Al}, \mathrm{S}$ and at $5 \%$ significance level for $\mathrm{K}^{+}$, no responses being observed to doses of ISS for $\mathrm{Na}^{+}$. These results are supported by the chemical characterisation of sewage sludge that altered the initial chemical characteristics of the soil. Moreover, as a result of the elevation of soil $\mathrm{pH}$, there is an increase in the capacity to provide nutrients to the plants (BOECHAT et al., 2015), and assistance in structuring the soil (BONINI et al., 2015) (Table 2). 
Table 6. ANOVA summary of soil $\mathrm{pH}$ in water $(\mathrm{pH})$, phosphorus $(\mathrm{P})$, potassium $\left(\mathrm{K}^{+}\right)$, calcium and magnesium $\left(\mathrm{Ca}^{2+}+\mathrm{Mg}^{2+}\right)$, exchangeable aluminum $\left(\mathrm{Al}^{+3}\right)$, potential acidity $(\mathrm{H}+\mathrm{Al})$, sodium $\left(\mathrm{Na}^{+}\right)$, and sum of bases (S) in soil cultivated with corn and fertilised with doses of industrial sewage sludge (ISS).

\begin{tabular}{llllllllll}
\hline \multirow{2}{*}{$\mathrm{SV}$} & $\mathrm{DF}$ & $\mathrm{pH}$ & $\mathrm{P}$ & $\mathrm{K}^{+}$ & $\mathrm{Ca}^{2+}+\mathrm{Mg}^{2+}$ & $\mathrm{Al}^{+3}$ & $\mathrm{H}+\mathrm{Al}$ & $\mathrm{Na}^{+}$ & $\mathrm{S}$ \\
\cline { 3 - 9 } Dose & 4 & $5.42^{*}$ & $3640.4^{*}$ & $0.01^{* *}$ & $4.00^{*}$ & $0.032^{*}$ & $1.64 *$ & $0.003^{\mathrm{ns}}$ & $0.28^{*}$ \\
Block & 3 & 0.005 & 14.00 & 0.01 & 0.39 & 0.003 & 0.02 & 0.0009 & 0.005 \\
Error & 12 & 0.04 & 12.60 & 0.004 & 0.17 & 0.003 & 0.02 & 0.0005 & 0.003 \\
\hline C.V. (\%) & & 3.06 & 7.01 & 25.30 & 15.53 & 129.10 & 37.49 & 34.75 & 6.11 \\
\hline
\end{tabular}

*- Significant effect at the $1 \%$ level of probability by F-test; **- Significant effect at the $5 \%$ level of probability by F-test; ns - not significant effect by F-test.

The $\mathrm{pH}$ directly influences plant development mainly regarding the availability and unavailability of nutrients in soil. The data showed a strong impact of wastes on the soil $\mathrm{pH}$ (Figure 2A). Under acid soil, higher doses have promoted a significant increase in the soil $\mathrm{pH}$. The high $\mathrm{pH}$ level was at a dose of $300 \mathrm{~kg} \mathrm{ha}^{-1}$. The ISS and DSS wastes raised soil $\mathrm{pH}$ from 5.2 to 7.7 and 5.9, respectively. These results may be related to the type of treatment that each of the sewage sludges individually received during the experiment. The ISS received significant quantities of $\mathrm{CaO}$ in the aeration pond, which explains the residual alkalinity and its greater ability to increase soil $\mathrm{pH}$. Bonini et al. (2015) showed opposite results from these. The authors analysed sewage sludge and mineral fertilisation for the recovery of chemical attributes of soil. They observed that the sewage sludge did not increase the $\mathrm{pH}$ in the studied doses.

Yet Moreira (2006) noticed a decrease in $\mathrm{pH}$ due to high doses of sewage sludge. Nevertheless, Boechat et al. (2014b), working with different sources of organic wastes, including wastes treated with $\mathrm{CaO}$, perceived an increase and decrease in $\mathrm{pH}$ related to the type of organic waste and its source. Therefore, it is necessary to know the form of treatment of the organic material to be used, and perform prior tests to analyse the effect of the doses of each material on soil $\mathrm{pH}$.

The soil P levels increased continuously, and a positive linear correlation was observed, as waste doses increased (Figure 2B). The ISS was outstanding because it promoted an increase in available $\mathrm{P}$ in soil, and the maximum value reached under a $300 \mathrm{~kg} \mathrm{ha}^{-1}$ dose. It is certainly related to the chemical characteristics of that waste (Table 2). The ISS waste presents the highest concentration of $\mathrm{P}$, and it was the waste the elevated the soil $\mathrm{pH}$ most. Thus, it provides more P. Under a $300 \mathrm{~kg} \mathrm{ha}^{-1}$ dose the values of $\mathrm{P}$ available were above $86.0 \mathrm{mg}$ $\mathrm{dm}^{-3}$ for ISS and $49.0 \mathrm{mg} \mathrm{dm}$ for DSS. These results can be explained by the fact that both wastes have a high level of P. Costa et al. (2014) found the same results assessing $\mathrm{P}$ available in the soil after the incorporation of sewage sludge until the $0.10 \mathrm{~m}$ deep layer between the years 2001 and 2006, five and ten days before sowing the corn.

Different behaviours were noted concerning the availability of $\mathrm{K}^{+}$and $\mathrm{Ca}^{+2}+\mathrm{Mg}^{2+}$ (Figures $2 \mathrm{C}$ and 2D). The statistical model was a quadratic function for ISS. The largest peak of $\mathrm{K}^{+}$available was under the dose of $100 \mathrm{~kg}$ total $\mathrm{N} \mathrm{ha}^{-1}$. This demonstrates that under high doses of ISS wastes, there may be a decrease in the availability of nutrients in the soil, and there was no difference for DSS in the $\mathrm{K}^{+}$content between the doses tested (Table 5).

In general, the treated and composed organic waste can present low quantities of $\mathrm{K}^{+}$in their composition due to the leaching process of this element resulting in poorer material during the phases of treatment. The ISS results were similar to those obtained by Trannin et al. (2008) who reported quadratic increases of this element in soil superficial layers with the application of industrial biosolids containing low $\mathrm{K}^{+}$levels. The occurrence of low concentrations of this element in sewage sludges requires its complementation in order to meet plant needs.

The greater availability of $\mathrm{Ca}^{2+}$ and $\mathrm{Mg}^{2+}$ was around the estimated value of $150 \mathrm{~kg} \mathrm{ha}^{-1}$. This shows that the availability of these nutrients may decrease when higher doses of that waste are added. On the other hand, the DSS waste showed a linear behaviour. Thus, higher values of $\mathrm{Ca}^{2+}+\mathrm{Mg}^{2+}$ were obtained at a dose of $300 \mathrm{~kg}$ total $\mathrm{N} \mathrm{ha}^{-1}$. Similar results were observed by Bonini et al. (2015) who found a positive increment for $\mathrm{Ca}, \mathrm{Mg}$ and $\mathrm{K}$ contents in the soil where eucalyptus and grass were planted after sewage sludge was applied. 

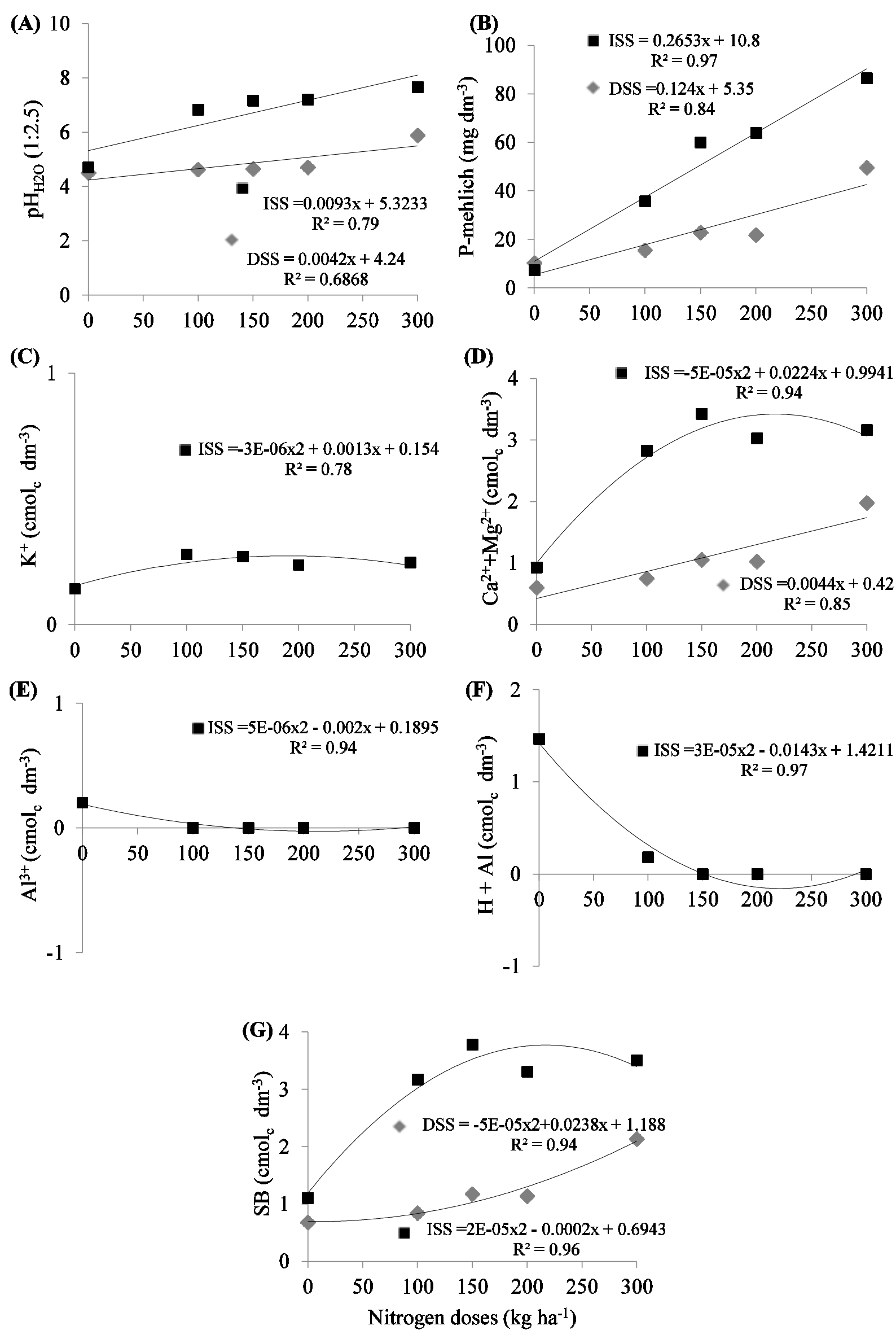

Figure 2. Chemical attributes of soil fertilised with doses of DSS ( $\bullet$ ) and ISS ( $\bullet$ ) with a corn crop. 
Industrial sewage sludge was able to reduce $\mathrm{Al}^{3+}$ availability and potential acidity in the soil (Figures 2E and 2F). This result is interesting because $\mathrm{Al}^{3+}$ at high levels compromises the development of most crops in Brazilian agriculture affecting plant root growth. The ISS was able to reduce the availability of $\mathrm{Al}^{3+}$ to zero from the dose of $100 \mathrm{~kg} \mathrm{ha}^{-1}$. However, there was no significant difference in these soil attributes at the tested doses of domestic sewage sludge (Table 5). The fact that the ISS waste was more efficient in reducing the availability of $\mathrm{Al}^{3+}$ can be attributed to its greater potential to elevate soil $\mathrm{pH}$, which is considered one of the major factors influencing the availability of this element. The levels of potential acidity decreased gradually as the dose of waste applied increased (Figure 2F). As to $\mathrm{Na}^{+}$availability, no significant increases were observed in the soil in response to the doses and types of sewage sludge studied (Tables 5 and 6).

For the sum of bases (SB), quadratic behaviour was observed after application of ISS, where the maximum value of $\mathrm{SB}$ is at the dose equivalent to approximately $220 \mathrm{~kg}$ total $\mathrm{N} \mathrm{ha}^{-1}$. Nevertheless, the DSS presented a quadratic adjustment with maximum SB at the dose of $300 \mathrm{~kg}$ $\mathrm{ha}^{-1}$. These results corroborate the values of $\mathrm{Ca}^{2+}$ found in soils after the application of increasing doses of sewage sludge. These values were close to those observed by Bonini et al. (2015) that found an increase of $\mathrm{Ca}$ in areas cultivated with eucalyptus and treated with a dose of $60 \mathrm{Mg} \mathrm{ha}^{-1}$ of domestic sludge. Thus, the value was similar to that contained in the natural vegetation in the layer $0.00-0.05 \mathrm{~m}$ of depth.

\section{CONCLUSIONS}

Increases in the doses of both sewage sludge provide gains in the studied morphological variables, except for the root length.

The number of leaves, stem diameter and fresh mass of root responded positively and linearly to the increase of both sewage sludge doses with the maximum yield at doses equivalent to $300 \mathrm{~kg}$ of $\mathrm{N}$ $\mathrm{ha}^{-1}$.

Positive linear increases occur in soil $\mathrm{pH}$ and phosphorus content with increasing doses of domestic and industrial sewage sludge.

The sewage sludges increase the sum of bases and $\mathrm{Ca}^{2+}+\mathrm{Mg}^{2+}$ contents with linear and quadratic adjustments.

The $\mathrm{K}^{+}$content in the soil is slightly increased when the dose of industrial sewage sludge is increased, and there is no significant change with domestic sewage sludge.

The exchangeable aluminium and the potential acidity are reduced after the first dose of industrial sewage sludge with no significant differences in the doses of domestic sludge for these response variables.

RESUMO: Nas últimas décadas a utilização de resíduos orgânicos e/ou inorgânicos não convencionais, como lodo de esgoto, resíduos agroindustriais ou industriais, rejeitos inorgânicos, escórias siderúrgicas, dentre outros, surgem como alternativas promissoras a escassez ou encarecimento dos fertilizantes comerciais. Diante do exposto, objetivou-se avaliar alterações morfológicas em plantas de milho e alterações nos atributos químicos de um Latossolo Amarelo coeso, após a incorporação de doses de lodos esgoto doméstico e da indústria de laticínios. Os experimentos foram instalados em um delineamento em blocos casualizados, com quatro repetições. Os tratamentos consistiram de cinco doses de cada lodo incorporadas ao solo, sendo: Lodo de esgoto doméstico (LD) nas doses de 0,0; 3,1; 4,6; 6,1 e 9,2 $\mathrm{Mg} \mathrm{ha}^{-1}$ (em base seca) e Lodo de esgoto industrial (LI) nas doses de 0,$0 ; 5,2 ; 7,8 ; 10,4$ e 15,6 $\mathrm{Mg} \mathrm{ha}^{-1}$ (em base seca), equivalentes a $0 ; 100 ; 150$; 200 e $300 \mathrm{~kg}$ de nitrogênio total ha ${ }^{-1}$. As doses equivalentes de 150 a $300 \mathrm{~kg}$ de $\mathrm{N} \mathrm{ha}^{-1}$ propiciaram maiores ganhos de diâmetro de colmo, número de folhas, massa fresca e massa seca de folhas. Aumentos nas doses de ambos os lodos de esgotos propiciam ganhos nas variáveis morfológicas estudadas, exceto para o comprimento de raízes. Incrementos lineares positivos ocorrem no $\mathrm{pH}$ e no teor de fósforo dos solos com o aumento das doses de lodos. O alumínio trocável e a acidez potencial são reduzidos, a partir da primeira dose de lodo de esgoto industrial, não havendo diferença significativa para o lodo doméstico.

PALAVRAS-CHAVES: Resíduo orgânico. Adubação orgânica. Descarte industrial. Descarte doméstico. Zea mays. 


\section{REFERENCES}

ALVES, M. C.; SUZUKI, L. G. A. S.; SUZUKI, L. E. A. S. Densidade do solo e infiltração de água como indicadores da qualidade física de um Latossolo Vermelho distrófico em recuperação. Revista Brasileira de Ciência do Solo, v. 31, p. 617-625, 2007. https://doi.org/10.1590/S0100-06832007000400002

BERILLI, S. S.; QUIUQUI, J. P. C.; REBINSKI, J.; SALLA, P. H. H.; BERILLI, A. P. C. G.; LOUZADA, J. M. Utilização de lodo de curtume como substrato alternativo para produção de mudas de café conilon. Coffee Science, v. 9, n. 4, p. 472-479, 2014.

BOECHAT, C. L.; SANTOS, J. A. G.; ACCIOLY, A. M. A.; BOMFIM, M. R.; SANTOS, A. C. Industrial and urban organic wastes increase soil microbial activity and biomass. Revista Brasileira Ciência do Solo, v. 36, p. 1629-1636, 2012. https://doi.org/10.1590/S0100-06832012000500027

BOECHAT, C. L.; RIBEIRO, M. O.; SANTOS, J. A. G.; ACCIOLY, A. M. A. Mineralizable nitrogen of organic wastes and soil chemical changes under laboratory conditions. Communications in Soil Science and Plant Analysis, v. 45, p. 1981-1994, 2014a. https://doi.org/10.1080/00103624.2014.919309

BOECHAT, C. L.; RIBEIRO, M. O.; RIBEIRO, L. O.; SANTOS, J. A. G.; ACCIOLY, A. M. A. Lodos de esgoto municipal e industrial no crescimento inicial e qualidade de mudas de Pinhão manso. Bioscience Journal, v. 30, p. 782-791, 2014b.

BOECHAT, C. L.; RIBEIRO, M. O.; BOMFIM, M. R.; BITTENCOURT, N. S.; ACCIOLY, A. M. A.; SANTOS, J. A. G. Sewage sludges in physic nut seedlings macronutrient contents and chemical attributes of soil. Bioscience Journal, v. 31, p.1378-1387, 2015. https://doi.org/10.14393/BJ-v31n5a2015-26413

BONINI, C. S. B.; ALVES, M. C. A; MONTANARI, R. Lodo de esgoto e adubação mineral na recuperação de atributos químicos de solo degradado. Revista Brasileira de Engenharia Agrícola e Ambiental, v. 19, n. 4, p. 388-393, 2015. https://doi.org/10.1590/1807-1929/agriambi.v19n4p388-393

CALDEIRA, M. V. W.; GONÇALVES, E. O.; TRAZZI, P. A.; DELARMELINA, M.; ROCHA, R. L. F. Crescimento de mudas de Eucalyptus grandis utilizando lodo de esgoto, fibra de coco e palha de café in natura. Floresta, v. 44, n. 2, p. 195-206, 2014. https://doi.org/10.5380/rf.v44i2.30170

CAMARGO, R.; MALDONADO, A. C. D.; SILVA, P. A.; COSTA, T. R. Biossólido como substrato na produção de mudas de pinhão-manso. Revista Brasileira de Engenharia Agrícola e Ambiental, v. 14, n. 12, p. 1304-1310, 2010. https://doi.org/10.1590/S1415-43662010001200008

CAMPOS, F. S.; ALVES, M. C. Uso de lodo de esgoto na reestruturação de solo degradado. Revista Brasileira Ciência do Solo, v. 32, n. 4, p. 1389-1397, 2008. https://doi.org/10.1590/S010006832008000400003

CARMO, M. S.; CRUZ, S. C. S.; SOUZA, E. J.; CAMPOS, L. F. C.; MACHADO, C. G. Doses e fontes de nitrogênio no desenvolvimento e produtividade da cultura de milho doce (Zea mays Convar. Saccharata var. rugosa). Bioscience Journal, v. 28, p. 223-231, 2012.

COSTA, V. L.; MARIA, I. C.; CAMARGO, O. A.; GREGO, C. R.; MELO, L. C. A. Distribuição espacial de fósforo em Latossolo tratado com lodo de esgoto e adubação mineral. Revista Brasileira de Engenharia Agrícola e Ambiental, v. 18, p. 287-93, 2014. https://doi.org/10.1590/S1415-43662014000300007

FERREIRA, D. F. Sisvar: a computer statistical analysis system. Ciência e Agrotecnologia, v. 35, n. 6, p. 1039-1042, 2011. https://doi.org/10.1590/S1413-70542011000600001

KORNDÖRFER, G. H.; VIEIRA, G. G.; MARTINS, J.; MATHIESEN, L. A. Resposta da cana planta a diferentes fontes de fósforo. Boletim Técnico Coopersucar, v. 45, n.1, p. 31-37, 1989. 
KITAMURA, A. E.; ALVES, M. C.; SUZUKI, L. G. A. S.; GONZALEZ, A.P. Recuperação de um solo degradado com a aplicação de adubos verdes e lodo de esgoto. Revista Brasileira de Ciência do Solo, v. 32, p. 405-416, 2008. https://doi.org/10.1590/S0100-06832008000100038

MAGALHÃES, A. C. Considerações sobre a fisiologia do sistema radicular: o caso das plantas cítricas. Laranja, v. 2, n. 9, p. 401-404, 1988.

MAGALHÃES, A. G.; ROLIM, M. M.; DUARTE, A. S.; BEZERRA NETO, E.; TABOSA, J. N.; PEDROSA, E. M. R. Desenvolvimento inicial do milho submetido à adubação com manipueira. Revista Brasileira de Engenharia Agrícola e Ambiental, v. 18, n. 7, p. 675-681, 2014. https://doi.org/10.1590/S141543662014000700001

MOREIRA, F. M. S.; SIQUEIRA, J. O. Microbiologia e Bioquímica do Solo. 2.ed. Lavras: Editora UFLA. 2006. 729p.

PIRES, A. M. M.; MATTIAZZO, M. E. Avaliação da viabilidade do uso de resíduos na agricultura. Jaguariúna: Embrapa, 2008. (Circular técnica)

RAMBO, L., SILVA, P. R. F. D., STRIEDER, M. L., SILVA, A. A. D., SANGOI, L.; VIEIRA, V. M. Nitrogen nutrition index and corn yield at different management and nitrogen fertilization levels. Pesquisa Agropecuária Brasileira, v. 46, n. 4, p. 390-397, 2011. https://doi.org/10.1590/S0100-204X2011000400008

SANTOS, H. G.; JACOMINE, P. K. T.; ANJOS, L. H. C.; OLIVEIRA, V. A.; LUMBRELAS, J. F.; COELHO, M. R.; ALMEIDA, J. A.; CUNHA, J. A.; OLIVEIRA, J. B. (Org.) Sistema Brasileiro de Classificação de Solos. 3.ed. rev. amp. Embrapa: Brasília, 2013. 353p.

SHABANI, H.; PEYVAST, G.; OLFATI, J.; KHARRAZI, P. R. Effect of municipal solid waste compost on yield and quality of eggplant. Comunicata Scientiae, v. 2, n. 2, p. 85-90, 2011.

SILVA, J. D. D. C., LEAL, T. T. B., ARAÚJO, R. M., GOMES, R. L. F., ARAÚJO, A. S. F. D.; MELO, W. J. D. Emergência e crescimento inicial de plântulas de pimenta ornamental e celosia em substrato à base de composto de lodo de curtume. Ciência Rural, v. 41, n. 3, p. 412-417, 2011. https://doi.org/10.1590/S010384782011000300008

SOIL SURVEY STAFF - SSS. Soil taxonomy - a basic system of soil classification for making and interpreting soil survey. 12th ed. Washington: USDA, 2014.

TEDESCO, M. J.; VOLKWEISS, S. J.; BOHNEN, H. Análise de solo, plantas e outros materiais. 2.ed. Porto Alegre: UFRGS, Departamento de Solos, 1995. (Boletim Técnico, 5).

THOMAZ, G. L.; ZAGONEL, J.; COLASANTE, L. O.; NOGUEIRA, R. R. Produção do girassol e teor de óleo nas sementes em diferentes épocas de semeadura no Centro-Sul do Paraná. Ciência Rural, v. 42, n. 2, p. 203-208, 2012. https://doi.org/10.1590/S0103-84782012005000010

TRANNIN, I. C. B.; SIQUEIRA, J. O.; MOREIRA, F. M. S. Atributos químicos e físicos de um solo tratado com biossólido industrial e cultivado com milho. Revista Brasileira de Engenharia Agrícola e Ambiental, v. 12, p. 223-230, 2008. https://doi.org/10.1590/S1415-43662008000300001

WALTER, I.; HIRZEL, J.; NOVOA, F.; UNDURRAGA, P. Short-term effects of poultry litter application on silage maize and soil chemical properties. Compost Science and Utilization, v. 17, n. 3, p. 189-196, 2009. https://doi.org/10.1080/1065657X.2009.10702421 